International Journal of Social Science and Economic Research

ISSN: 2455-8834

Volume: 05, Issue: 04 "April 2020"

\title{
AN OVERVIEW OF FEMALE-LED STARTUPS IN INDIA
}

\author{
Aadya Agarwal \\ The International School of Bangalore \\ DOI: 10.46609/IJSSER.2020.v05i04.011 URL: https://doi.org/10.46609/IJSSER.2020.v05i04.011
}

\begin{abstract}
Over the past decade, startups have been drivers of innovation and economic growth, a trend that is becoming increasingly prevalent in developing countries. Establishing a startup in India is a challenging task, irrespective of the founder's gender. However, there has been growing discourse about the absence of a level playing field between male and female entrepreneurs. Reports by the government and international agencies show that only $10 \%$ of the startups that have established long term operations in India have been founded or are led by women, most of which have been self-financed. This paper has examined the social and structural barriers to women in business. Negative stereotyping, responsibilities of childcare, lower rates of literacy, the lack of public safety and the presence of a negative bias against women in the workforce reduces the ability and willingness of women to undertake entrepreneurial ventures. This is a part of the larger problem of the lack of participation of women in the Indian workforce and leads to wastage of potential for economic growth. This paper also provides policy recommendations that are necessary to create an environment that is conducive to female-led entrepreneurship.
\end{abstract}

Keywords: Startups, Female entrepreneurs, Self-employment, Business, Economic growth

\section{INTRODUCTION}

A startup is defined as a company that is in the first stage of its operations. These companies are often initially floated by their entrepreneurial founders as they attempt to capitalize on developing a product or service for which they believe there is a demand. Startups seek to effectively develop, and validate a scalable business model. Startups differ from general entrepreneurship ventures because they intend to grow beyond the founders, have employees, and intend into large scale enterprises whereas general entrepreneurial ventures include also include all forms of self-employment and businesses that never intend to grow into registered corporations (Robehmed, 2013). Startups have been at the center of innovations in business for the past two decades, and their contribution to economic activity and productivity has 


\section{International Journal of Social Science and Economic Research}

ISSN: $2455-8834$

Volume: 05, Issue: 04 "April 2020"

significantly increased. The growth of startup businesses can be attributed to significant technological advancements in the 21st century and the creation of an infrastructure that is conducive for the growth of new businesses and is characterized by the availability of investments, and state support. However, the most important reason for the growth of startups in the 21 st century is the need and ability of individuals to sustain themselves whilst also pursuing innovations through self-employment. Startups are innovative because they do not conform to typical market behavior but instead seek to disrupt markets. Startup companies are also considered to be a positive force in society also because it allows individuals to independently actualize their potential and ideas in a capitalistic economy, in which the will of the individual is often subverted to the will of corporations and individuals have no autonomy over their work. Even though startups have been key for personal development and socio-economic growth, the ability of certain identities and communities from starting new entrepreneurial ventures is hampered due to social conditions and beliefs.

The growth of the Indian economy over the last decade has been characterized by a 'culture' that encourages the creation of startups and new businesses in the country. The Sixth Economic Census of India has found that a majority of these startups have been founded by men (MSPI, 2014). The lack of female-led startups does not represent the lack of ambitions towards entrepreneurship amongst Indian women but is reflective of the unfair playing field and additional barriers and challenges that only women have to face to succeed. The 'ease' of doing business in India has been a cause of concern for the Indian Government. India is in a group of countries where women business owners (as well as women leaders and professionals) struggle with less favorable conditions, pronounced cultural biases, and a lack of business resources such as finances, capital, training, and development (Mastercard, 2018). Social barriers and individual behavior that prevents women from actualizing their potential independently are considered to be the by-products of the larger patriarchal belief system and social structure that exists in India.

Female businesses are one of the fastest-growing entrepreneurial populations at the international level. Moreover, they have made significant contributions to the innovation, employment, and wealth creation of all economies around the world (Jennings \& Brush, 2013). They also offer an answer in terms of self-employment to overcome the crisis of unemployment afflicting certain economies. However, the empowerment of women in the main entrepreneurial ecosystems is still contained, and never exceeds $18 \%$ of the population of startups in developing countries (Startup Genome 2018). In rational terms, the fact that women do not actively participate in the economic growth of GDP is undoubtedly a loss not only of wealth but also of competitiveness, especially in a knowledge economy in which the entrepreneurial capital is increasingly a precious resource for the development of a country. The 'Startup Culture' is one that is based on free-market principles of innovation and competitiveness which ultimately leads to individual prosperity and 


\section{International Journal of Social Science and Economic Research}

ISSN: $2455-8834$

Volume: 05, Issue: 04 "April 2020"

social development. The inequality in the playing field of entrepreneurs creates an environment that discriminates between entrepreneurs based on their gender is not only detrimental to the possibility of growth of female-led ventures but also the larger socio-economic development of the country.

\section{BACKGROUND}

The lack of participation of women in the startup culture is a part of the larger problem of lower participation of women in the workforce of India. Despite high economic growth rates as well as an increase in the proportion of working-age women in the population, the participation of women in the workforce has decreased from 35 percent in 2005 to just 26 percent in 2018 (The Economist, 2018). The World Economic Forum's report on the gender wage gap found that India's gender gap is caused by the lack of economic participation and opportunity for women (World Economic Forum, 2018). The Report ranked India 108th out of 142 surveyed countries whilst assessing the gender pay gap. Women in India have fewer opportunities to become business leaders, professionals, and technical workers. According to a World Bank Enterprise Survey, the percentage of women in leadership positions in 2014 was as low as nine percent (World Bank Enterprise Survey, 2014). The fact that few women own companies are part of a larger phenomenon of weak engagement of women in business. The low rates of women entrepreneurship are reflected through the Index of Women Entrepreneurs, where India is ranked 52nd out of the 57 surveyed countries (The Economist, 2018). The Sixth Economic Census was conducted between January 2013 and April 2014 by the Ministry of Statistics and Programme Implementation. It found that out of 58.5 million businesses counted, only 8.05 million were owned by women, which corresponds to a rate of 13.76 percent of women among the total number of entrepreneurs in India (MSPI, 2014). The World Bank Enterprise Survey, meanwhile, found that in 2014, the percentage of firms with female participation in ownership was $10.7 \%$

Globally, research has linked limited resources, lack of access to capital markets and social networks, the lack of appetite for business amongst women, and differing definitions for success amongst men and women. Research on psychological causes have been inconclusive, strong links can be found between indicators of development amongst women and their presence in the public sphere and markets. In India, for example, lower rates of literacy and the lack of access for women to formal education are considered to be reasons for lower participation in entrepreneurship. The top five states with the highest percentage of women entrepreneurs in India- Tamil Nadu, Kerala, Andhra Pradesh, West Bengal, and Maharashtra are the ones with relatively high literacy rates (Samantroy \& Tomar, 2018). Even though states including Kerala and the North-East have higher rates of education, the scope for entrepreneurship in those regions is limited due to the lack of access to capital for all genders. 


\section{International Journal of Social Science and Economic Research}

ISSN: $2455-8834$

Volume: 05, Issue: 04 "April 2020"

To solve the problem of the lack of participation of women in business, the Government of India has launched multiple schemes that seek to incentivize women to engage in entrepreneurship. The Mudra Yojana Scheme is a general scheme under which women are given loans of up to Rs 10 lakh without any collateral for setting up small scale enterprises. (Mansur, 2019) The TradeRelated Entrepreneurship Assistance and Development scheme aims to empower female entrepreneurs by conducting specific training and counseling and eliciting information on related needs to provide financial and non-financial assistance (Mansur, 2019). Under the Bhartiya Mahila Business Bank Loan Scheme, the government provides a loan of up to Rs 20 crore at low-interest rates is provided to women who own manufacturing enterprises. Public Sector Banks seek to promote entrepreneurship amongst women by extending credit by running independent programs such as the Cent Kalyani Scheme (Central Bank of India) and the Dena Shakti Scheme (Dena Bank) (Mansur, 2019). Most of these schemes have been introduced over the past decade which makes it difficult to evaluate their success. However, there is a need for contextualized and nuanced solutions that eliminate social barriers that prevent the participation of women in the economy, and more specifically in the sphere of innovative entrepreneurship.

\section{DISCUSSION}

Creating a successful startup in an environment as competitive as India's is difficult irrespective of the gender of the founders. Key challenges for startups in India include generating sufficient funding, lower-skill development, and a complex regulatory environment. For women entrepreneurs, however, there are additional barriers that are part of a broader and more pronounced gender gap in the male-dominated Indian society. Unconscious gender bias is defined as unintentional and automatic mental associations based on gender, stemming from traditions, norms, values, culture and/or experience (ILO, 2017). It is a key factor impeding the progress of women entrepreneurs, especially in developing countries like India. Automatic associations enable quick assessment of an individual and often feed into decision-making that is unfavorable towards women. Frequently-repeated stereotypes reinforce the belief that men are more competent when it comes to financial matters. This reflects in the unfair treatment of female founders at the hands of investors and reduces the propensity of generating seed capital and funding, which is considered to be necessary for sustaining startups beyond a particular point. Continuously countering negative perceptions harms the ability of any manager or entrepreneur to make decisions and effectively manage an undertaking. Research has suggested that negative stereotypes reduce the self-confidence of female entrepreneurs which renders them less likely to take the initiative of starting new companies (Korreck, 2019). It has been observed that even highly successful women often struggle with self-doubt and underestimate their abilities and performance, while the opposite has been observed for men (Katty \& Shipman, 2015). Indian women also face problems in procuring finance and loans as they rarely own 


\section{International Journal of Social Science and Economic Research}

ISSN: $2455-8834$

Volume: 05, Issue: 04 "April 2020"

property, which is often used by entrepreneurs as collateral for loans. Moreover, families are less likely to support their daughters' entrepreneurial ventures financially than their sons'. About 79 percent of women-owned ventures are self-financed. Only a small section of women in India have the financial ability to sustain their startup. This implies that the lack of access to finance excludes the vast majority of potential female entrepreneurs.

Masculine corporate cultures are one of the most-cited barriers to women's leadership. Founders of companies including Flipkart have been accused of sexual harassment by their female employees. A hypermasculine work environment alienates women and leads to lower rates of participation of women in prominent industry networks (Korreck, 2019). This impedes the progress of women entrepreneurs and female-led startups because of the importance of networking in niche markets in India, which startups tend to explore. Indian women assume greater responsibility at home and spend, on average, five times as much time than men on housework, household care, and other unpaid activities. Even if this behavior is voluntary on the part of women, this trend is considered to be a cause of social conditioning (King \& Jones, 2016). The absence or presence of support for female entrepreneurs plays a role in determining levels of non-financial investment by female entrepreneurs in their startups. Society places the burden of childcare on women. This puts an exclusive burden on female founders and forces them to make difficult trade-offs between work and family (Brooks, et. al., 2014). Access to paid childcare is also restricted on economic grounds. Lastly, safety at the workplace and in public spaces continues to be a pressing concern for women who work. High rates of sexual violence against women have restricted the access of women from seemingly fair economic and investment opportunities (Brooks, et. al., 2014).

Female entrepreneurship is important not only because it stimulates economic activity and development but also because it leads to the introduction of unique perspectives to the business. Innovation and market creation is often dependent on the ability of companies to understand consumer needs, which are often derivative of this experience. In a business environment that is characterized by the hegemony of well-established companies, most of which are male-led; female-led startups hold the unique value of stimulating innovation that stems from female experiences in society. Research conducted in the United States of America suggests that femaleled startups have outperformed companies founded by men in many parameters of progress. According to the Kauffman Foundation, private technology companies led by women are 35\% more capital-efficient, 12\% more profitable than startups run by men (Kapin, 2019). Research conducted by the Boston Consulting Group also suggests that female led-starts generate higher rates of return for investors over the first five years of business. (Matthew, 2019) A report by Forbes published in 2019 suggests that the workforce of startups led by women is more diverse, which often contributes to a more conducive work environment (Kapin, 2019). 


\section{International Journal of Social Science and Economic Research}

ISSN: $2455-8834$

Volume: 05, Issue: 04 "April 2020"

\section{CONCLUSION}

The actualization of the true potential of female-centric and female-led entrepreneurs can promote innovation, economic growth, and job creation. However, this is contingent on interventions that tackle structural and social barriers. The low women entrepreneurship rates are reflective of a broader gender gap in economic participation and access to opportunities. Thus, it is crucial to provide equal access to education and encourage women to use their acquired skills by joining the workforce. Policies by the state or companies themselves which are aimed at including more women in senior and leadership positions are needed as they help women in the business community gain experience and knowledge key to establishing an enterprise (Korreck, 2019). Second, awareness around unconscious biases against women and male privilege needs to be generated to promote discourse and emancipatory action. Female entrepreneurs in India should be provided better access to finance and networks. The effect of state-sponsored finance schemes that provide cheap and convenient finance is limited because their activities are restricted in the informal sector. Networking and integrating informal female-led businesses with formal markets and financial organizations in important to channel private and public investment. Even if individual businesses are led by female entrepreneurs, interactions with other companies that a startup engages with regularly can lead to the creation of a toxic work environment, as it has in the technology sector. More inclusive, non-discriminatory, and safe work environments are important to retain qualified women. There needs to be a stronger emphasis on measures that seek to make public space safer in India. Concerns regarding safety in commute put a significant mental load on women. Lastly, there is a need to generate sensitivity from society. The growth of businesses is often contingent on the communities that surround it. Cognizance of the unique need and value of female-led entrepreneurship can lead to positive behavior from the families of founders and the public in general.

Positive trends in female entrepreneurship in India have emerged over the past year. In 2019 women-led and co-founded companies raised a total of \$487 million as compared to 2018 when the total funding received was $\$ 274$. The total number of funding deals involving women-led startups rose 11 percent from 2018 to 2019. As suggested by the trends, there is immense potential for the development of female entrepreneurship in India, the actualization of which is contingent on policies that are fundamentally guided by the reimagination of society and business from a lense centered around female experiences and leadership. 


\section{International Journal of Social Science and Economic Research}

ISSN: $2455-8834$

Volume: 05, Issue: 04 "April 2020"

\section{BIBLIOGRAPHY}

Brooks, A.W, Huang, L. Keanery, S.W, Murray, F.E. (2014). Investors Prefer Entrepreneurial Ventures Pitched by Attractive Men. Proceedings of the National Academy of Sciences of the United States of America . Accessed on 25th November 2019

International Labour Organization. (2017). Research Note, Breaking Barriers: Unconscious Gender Bias in the Workplace. Accessed on 24th November 2019

Jennings, J.E. \& Brush, C.G. (2013). Research on women entrepreneurs: Challenges to (and from) the broader entrepreneurship literature? The Academy of Management Annals, Accessed on 23rd November 2019

Kapin, A. 10 Stats That Build The Case For Investing In Women-Led Startups. Forbes, 28th January, 2019

Kay, K. \& Shipman, C. (2014). The Confidence Gap. The Atlantic. 10th May 2014.

Mansur, R. MSME Funding: Nine schemes for women entrepreneurs in India. Yourstory, 2nd April, 2019

Mastercard (2018). Mastercard Index of Women Entrepreneurs. Accessed on 21st November 2019

Matthew, A. (2019). Making It In India. Boston Consulting Group, Accessed on 25th November 2019

King, E. \& Jones, K. (2016). Why Subtle Bias is so Often Worse than Blatant Discrimination. Harvard Business Review, Accessed on 21st November 2019

Korreck, S. (2019). Women Entrepreneurs in India: What is holding them back? Issue Briefs and Special Report. Accessed on 21st November 2019

Ministry of Statistics and Programme Implementation. (2014). Highlights of the Sixth Economic Census. Accessed on 24th November 2019

Robehmed, N. (2013). What Is A Startup?. Forbes. Accessed on 22th November 2019

Samantroy, E. \& Tomar, J.S. (2018). Women Entrepreneurship in India: Evidence from Economic Consensus. Social Change. Accessed on 24th November 2019 
International Journal of Social Science and Economic Research

ISSN: 2455-8834

Volume: 05, Issue: 04 "April 2020"

Startup Genome. (2018). Global Startup Ecosystem Report 2018. Accessed on 22th November 2019

The Economist. (2018). Women in India: How India Fails its Women. Accessed on 23rd November 2019

World Bank Enterprise Survey. (2014). Firms with Female Top Managers (\% of Firms. Accessed on 24th November 2019

World Economic Forum. (2018). The Global Gender Gap Report 2019. Accessed on 22th November 2019 